\title{
Oxygen as an exchangeable ligand in soil
}

\author{
ERKKI AURA ${ }^{1}$ ) \\ Department of Agricultural Chemistry, University of Helsinki 00710 Helsinki 71
}

\begin{abstract}
An attempt was made to clarify the adsorption of oxygen ligands onto the Al- and Fe-oxides in the soil. In the ligand exchange the central ions $\mathrm{Al}^{3+}$ and $\mathrm{Fe}^{3+}$ of the oxides are Lewis acids or electron acceptors and the ligands are Lewis bases or electron donors. The binding of ligand oxygen by the central ion is primarily dependent on the nucleophilic strength of the ligand oxygen. The proton is a hard Lewis acid as are $\mathrm{Al}^{3+}$ and $\mathrm{Fe}^{3+}$. The pKa-value of the acid corresponding to the anion shows the ability of ligand oxygen to bind a proton and also the ability to bind $\mathrm{Al}^{3+}$ and $\mathrm{Fe}^{3+}$. The greater the nucleophilic strength of the ligand, the more covalent the nature of the bond between ligand oxygen and the central ion. However, the covalent character of this bond does not make the adsorption of a ligand by oxides an exothermic reaction. The entropy changes in adsorption determine the exchange equilibritum of the anions. The nucleophilic strength of ligand oxygen also determines the rate of exchange. If an anion has a high nucleophilic strength, it is rapidly adsorbed by oxides but the desorption is slow. The theory explains the relationship between the adsorption of anions to oxides and the $\mathrm{pH}$-value in the equilibrum solution. The theory also illuminates the factors, which determine the leaching of an anion from the soil and the uptake rate of an anion from the soil by plants.
\end{abstract}

\section{Introduction}

The oxygen is the most abundant chemical element in the soil. This is due to the fact that the earth's crust contains $46.6 \%$ oxygen by weight (WEAST 1969). The oxygen plays an important role in the most reactive components of soil. This chemically active part of the soil consists of soil organic matter, clay minerals and polymeric $\mathrm{Al}$ - and Fe-oxides. The most reactive groups of the soil organic matter are the carboxyl and phenolic $\mathrm{OH}$ groups. These are able to bind a proton or another cations (Schnitzer 1978). In the clay minerals the central ions (e. g. $\mathrm{Si}^{4+}, \mathrm{Al}^{3+}, \mathrm{Fe}^{3+}$ ) are surrounded by negatively charged oxygen ions in tetrahedral or octahedral layers. In the amorphous or crystallized $\mathrm{Al}$ - and Fe-oxides the central ions are surrounded by six oxygen atoms.

1) Present adress: Institute of Soil Chemistry and Physics, Agricultural Research Centre 31600 Jokioinen. 
The polymeric Al- and Fe-oxides of the soil are very porous substances. In the amorphous form their specific surface area is over $100 \mathrm{~m}^{2} / \mathrm{g}$ (e. g. RAJAN et al. 1974, PARfitT et al. 1975). The great specific surface shows, that the amorphous oxides have plenty of pores, which have a diameter in the order of small molecules (PARFITT 1971). The oxide polymers do not always exist as separate paricles in soil. The aluminium oxides specially form layers on the surface of clay particles (CLARK 1964). The aluminium and iron oxides can also be attached to the soil organic matter by various chemical bonds.

The surfaces of polymeric $\mathrm{Al}$ - and $\mathrm{Fe}$-oxides are the anion exchangers in the soil. If the oxygen atom is situated internaly in oxides, it is bound by more than one $\mathrm{Al}^{3+}$ (or $\mathrm{Fe}^{3+}$ )-ion. In this case the oxygen is inactive in the soil. Whereas on the surface of the oxides, oxygen can be attached to only one aluminium or iron ion and can also be a part of the structure of the following anions or ligands: water, hydroxyl, sulphate, phosphate, carbonate, selenite, molybdate, borate, silicate and the carboxyl and phenolic $\mathrm{OH}$ group of organic matter. These anions are not always coordinated on the surface of oxides. For example a part of phosphate is blocked in oxides due to the precipitation reactions of phosphate in the soil. However, primarily the anions that are adsorbed on the pore surface of the oxides participate in exchange reactions.

The anion exchange in the soil is of great importance e. $\mathrm{g}$. in the plant nutrition. The purpose of this study was to examine the factors, which effect the coordination of the ligand oxygen with the central ions of $\mathrm{Al}$ - or Fe-oxides. The factors influencing the rate of exchange were also considered. The emphasis was laid on the bonding of oxygen to the central ion. The effect of the detailed structure of oxides on the coordination was not examined.

\section{Central ions of oxides and ligand exchange}

The theory of acids and bases presented by PEARSON (1966) seems to be very useful in the study of ligand exchange in soil: In the ligand exchange the central ions $\mathrm{Al}^{3+}$ and $\mathrm{Fe}^{3+}$ are Lewis acids or electron acceptors and ligands are Lewis bases or electron donors. The ions $\mathrm{Al}^{3+}$ and $\mathrm{Fe}^{3+}$ belong to the group of hard Lewis acids. These ions have the distinguishing property of small size and high positive oxidation state. Hard acids prefer to associate with hard bases. The latter have low polarizability and high electronegativity. The donor atom is often $\mathrm{O}$, but can also be $\mathrm{F}$ or $\mathrm{N}$.

The acidic property of $\mathrm{Al}^{3+}$ and $\mathrm{Fe}^{3+}$ in water solution is due to the fact that the oxygen from six water molecules around the $\mathrm{Al}^{3+}$ or $\mathrm{Fe}^{3+}$ ions are electron donors, which aids the detachment of a proton from the coordinated water molecule. The electrons of oxygen are shared more strongly with $\mathrm{Fe}^{3+}$ than with $\mathrm{Al}^{3+}$. The acid hydrolysis constant is 5.0 at $25^{\circ} \mathrm{C}$ for $\mathrm{Al}^{3+}$ and 2.2 for $\mathrm{Fe}^{3+}$ (Hunt 1963, p. 50). Due to the decrease of charge in hydrolysis, the monomeric $\mathrm{Al}\left(\mathrm{H}_{2} \mathrm{O}\right)_{5} \mathrm{OH}$ or $\mathrm{Fe}\left(\mathrm{H}_{2} \mathrm{O}\right)_{5} \mathrm{OH}$ tend to polymerize. In water solutions ferric ions polymerize readily above $\mathrm{pH} 2$ and aluminium ions above pH 5 (e. g. Jackson 1960, Murphy et al. 1975). Polymerization can be seen as a ligand exchange. The OH-group attached to the central ion is exchanged by the oxygen which is bound by the other central ion. For example: 


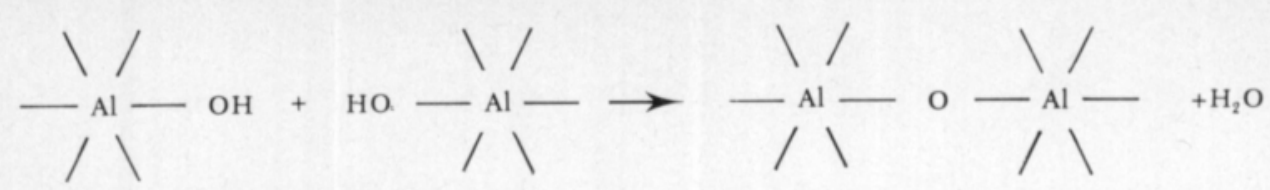

The reduction of $\mathrm{Fe}^{3+}$ to $\mathrm{Fe}^{2+}$ decreases greatly the ability of iron to bind the electrons of the oxygen ligand. Consequently the acid hydrolysis constant of $\mathrm{Fe}^{2+}$ at $25^{\circ} \mathrm{C}$ is as high as 9.5 (BAsolo and PEARson 1967, p. 32). In reductive conditions the iron oxides tend to break up and $\mathrm{Fe}^{2+}$ is easily released from oxides as a monomeric cation.

\section{The chemical bond between the oxygen ligand and central ion of oxides}

The binding of oxygen by the central ion is primarily dependent on the nucleophilic strength of the oxyanion or ligand. The cation $\mathrm{H}^{+}$is the prototype hard Lewis acid and any base which binds strongly to the proton will also bind to other hard acids as well (PEARson 1966). The pKa-value of the acids corresponding the oxyanions shows the ability of anion oxygen to bind a proton and also the nucleophilic strength. The higher the pKa-value the more stable is the bond between oxygen and the central ions $\mathrm{Al}^{3+}$ and $\mathrm{Fe}^{3}$ (EDWARDS 1956, Pearson 1966). Edwards (1956) has shown that the nucleophilic character of the donor depends on both the basicity of the ligand and also on the ease with which the donors polarize. The ability of the ligand to coordinate to the central atom, when it is a hard Lewis acid, is primarily related to the basicity of the ligand (Edwards and Pearson 1962, Pearson 1966).

Table 1. The pKa-values of acids corresponding to the ligands (SASAKI et al. 1959, WeAst 1969).

\begin{tabular}{lll}
\hline Ligand & Acid & $\mathrm{pKa}\left(25^{\circ} \mathrm{C}\right)$ \\
\hline $\mathrm{H}_{2} \mathrm{O}$ & $\mathrm{H}_{3} \mathrm{O}^{+}$ & -1.74 \\
$\mathrm{NO}_{3}^{-}$ & $\mathrm{HNO}_{3}$ & \\
$\mathrm{HSO}_{4}^{-}$ & $\mathrm{H}_{2} \mathrm{SO}_{4}$ & \\
$\mathrm{SO}_{4}^{-}$ & $\mathrm{HSO}_{4}^{-}$ & 1.92 \\
$\mathrm{H}_{2} \mathrm{PO}_{4}^{-}$ & $\mathrm{H}_{3} \mathrm{PO}_{4}$ & 2.12 \\
$\mathrm{HSeO}_{3}^{-}$ & $\mathrm{H}_{2} \mathrm{SeO}_{3}$ & 2.46 \\
$\mathrm{MoO}_{4}^{-}$ & $\mathrm{HMoO}_{4}^{-}$ & 4.1 \\
$\mathrm{HCO}_{3}^{-}$ & $\mathrm{H}_{2} \mathrm{CO}_{3}$ & 6.37 \\
$\mathrm{HPO}_{4}^{-}$ & $\mathrm{H}_{2} \mathrm{PO}_{4}^{-}$ & 7.21 \\
$\mathrm{SeO}_{3}^{-}$ & $\mathrm{HSeO}_{3}^{-}$ & 7.31 \\
$\mathrm{H}_{2} \mathrm{BO}_{3}^{-}$ & $\mathrm{H}_{3} \mathrm{BO}_{3}$ & $9.14\left(20^{\circ} \mathrm{C}\right)$ \\
$\mathrm{H}_{3} \mathrm{SiO}_{4}^{-}$ & $\mathrm{H}_{4} \mathrm{SiO}_{4}$ & $9.66\left(30^{\circ} \mathrm{C}\right)$ \\
$\mathrm{CO}_{3}^{-}$ & $\mathrm{HCO}_{3}^{-}$ & 10.25 \\
$\mathrm{PO}_{4}^{3-}$ & $\mathrm{HPO}_{4}^{-}$ & $12.67\left(18^{\circ} \mathrm{C}\right)$ \\
$\mathrm{OH}^{-}$ & $\mathrm{H}_{2} \mathrm{O}^{-}$ & 15.74 \\
\hline
\end{tabular}

The pKa-values of the most usual inorganic ligands are shown in Table 1. If the pKa-value is high, the anion concentration in the equilibrium solution in contact with acid soil is low, because the anion ligand tends to be strongly bound to both $\mathrm{Al}^{3+}\left(\mathrm{Fe}^{3+}\right)$ and $\mathrm{H}^{+}$. The anions of polyprotic acids can be 
bound to two adjacent central ions on the surface of the oxide pores forming a ring structure (PARFitT et al. 1975, PAREITt and Smart 1978, Rajan 1978). This binuclear bridging probably increases the stability of the coordination (Hingston et al. 1974). Since the polymeric Al- and Fe-hydroxides probably contain plenty of micropores then the size of the ligand will effect the adsorption of the ligand to the surfaces of the pores. The pKa-value of an acid corresponding to the ligand reveals something about the character of the bond between the oxygen and the central ion $\mathrm{Al}^{3+}$ or $\mathrm{Fe}^{3+}$. The greater the nucleophilic strength of the donor, the more covalent character of the bond. The hydroxyl oxygen, which has three unshared electron pairs, probably forms both $\sigma$ - and $\pi$-bond with $\mathrm{Fe}^{3+}$ and $\mathrm{Al}^{3+}$-ions (BARAN 1971).

\section{The changes of standard enthalpy and entropy in ligand exchange}

The covalent character of the strong bond between the oxygen ligand and the central ion does not make the adsorption of the ligand by oxides an exothermic reaction. When an anion exchanges from the surface of oxides e. g. a water molecule, energy is consumed for the detachment of $\mathrm{H}_{2} \mathrm{O}$ from the central ion and also for the decresae of the hydration number of the anion. Often the change of the standard entropy primarily determines the equilibrium of the ligand exchange in the soil. According to the Van't Hoff equation the equilibrium constant $\mathrm{K}$ of the chemical reaction is dependent on the temperature as follows:

$$
\text { 1n } K=\frac{-\Delta H^{\circ}}{R} \frac{1}{T}+\text { constant }
$$

where

$$
\begin{aligned}
\Delta \mathrm{H}^{\circ} & =\text { the change of the standard enthalpy } \mathrm{J} / \mathrm{mol} \\
\mathrm{R} & =\text { the gas constant } 8.314 \mathrm{~J} / \mathrm{K} \mathrm{mol} \\
\mathrm{T} & =\text { the absolute temperature } \mathrm{K}
\end{aligned}
$$

When an anion $\mathrm{A}^{-}$exchanges with the ligand water, the equilibrium constant $\mathrm{K}$ can be defined as follows:

$$
\begin{aligned}
\mathrm{K}=\frac{\mathrm{A}_{1}^{-}+\mathrm{H}_{2} \mathrm{O}_{\mathrm{s}}}{\left(\mathrm{A}_{1}\right)_{2} \quad \mathrm{X}_{\mathrm{H}_{2} \mathrm{O}} \mathrm{O}} & \rightarrow \frac{\mathrm{A}_{\mathrm{s}}^{-}+\mathrm{H}_{2} \mathrm{O}_{1}}{\left(\mathrm{~A}_{1}\right)_{1} \quad \mathrm{X}_{\mathrm{H}_{2} \mathrm{O}}}
\end{aligned}
$$

where

$$
\begin{aligned}
&\left(A^{-}\right)_{1}= \text { the activity of anion } A^{-} \text {in the equilibrium solution } \\
&\left(\mathrm{H}_{2} \mathrm{O}\right)_{1}= \text { the activity of water in solution } \approx 1 \\
& \mathrm{X}_{\mathrm{A}}=\text { the mole fraction of } \mathrm{A}^{-} \text {on the surface of oxides. } \text { The activity coefficient of } \mathrm{A}^{-} \text {has the value of } 1 . \\
& \mathrm{X}_{\mathrm{H}_{2} \mathrm{O}=}=\text { the mole fraction of } \mathrm{H}_{2} \mathrm{O} \text { on the surface of oxides. } \\
& \text { The activity coefficient of } \mathrm{H}_{2} \mathrm{O} \text { has the value of } 1 .
\end{aligned}
$$

If there are no other ligands than $\mathrm{A}^{-}$and $\mathrm{H}_{2} \mathrm{O}$, it follows that $\mathrm{X}_{\mathrm{H}_{2} \mathrm{O}}=1-\mathrm{X}_{\mathrm{A}}$. Combining this with the equation (3) we get the Langmuir adsorption equation for the sorption of $\mathrm{A}^{\bar{*}}$ :

$$
\mathrm{X}_{\mathrm{A}}=\frac{\mathrm{K}\left(\mathrm{A}^{\top}\right)_{1}}{1+\mathrm{K}\left(\mathrm{A}^{\top}\right)_{1}}
$$

The coefficient $\mathrm{K}$ is constant only if all the adsorption sites have the same standard free energy of adsorption. In reality $\mathrm{K}$ is not constant. The appli- 
cability of the Langmuir equation can be improved using the equation of the two adsorption surfaces (SYERS et al. 1973). For simplicity the conventional Langmuir equation is used in this study.

Hartikainen (1979) has studied with several acid soil samples, how the phosphate concentration in the equilibrium solution in contact with soil depends on the temperature. This had no effect on the concentration or the influence was slightly positive or negative. The equation (1) shows that the change of the standard enthalpy in the adsorption of phosphate is small. Since

$$
\begin{aligned}
& \Delta \mathrm{G}^{\circ}=-\mathrm{RT} \ln \mathrm{K} \\
& \Delta \mathrm{G}^{\circ}=\Delta \mathrm{H}^{\circ}-\mathrm{T} \Delta \mathrm{S}^{\circ}
\end{aligned}
$$

where

$$
\begin{aligned}
& \Delta \mathrm{G}^{\circ}=\text { the change of free energy } \mathrm{J} / \mathrm{mol} \\
& \Delta \mathrm{S}^{\circ}=\text { the change of entropy } \mathrm{J} / \mathrm{mol} \mathrm{K}
\end{aligned}
$$

the entropy changes determine the equilibrium of phosphate adsorption in acid soils. The phosphate anion in solution and the central ion on the surface of $\mathrm{Al}$-and Fe-oxides increase the order of water molecules in the solution. The attachment of phosphate oxygen to the $\mathrm{Al}^{3+}$ or $\mathrm{Fe}^{3+}$ neutralize the charges of these ions, which increases the disorder of water molecules in the solution.

Biggar and Fireman (1960) have stated that the adsorption of borate to soil becomes slightly weaker, when the temperature rises. In the studies of Bingham et al. (1971) the effect of the temperature was to bind borate anions more strongly, which shows that the reaction was endothermic. Hingston and RAUPACH (1967) have studied the sorption of silicate to the Al-hydroxy polymers and found that adsorption of first silicate layer on the surface of the oxides was almost independent of the temperature. The measurements of REYES and JURINAK (1967) showed no relationship between the temperature and adsorption of molybdate by hematite, when the concentration of molybdate was not high in the equilibrium solution.

The nucleophilic strength of ligand oxygen is closely related to the amount of negative charge associated with ligand oxygen. The higher the pKa-value of the acid corresponding to the anion ligand is, the more the charge is concentrated on the ligand oxygen and the more effectively the ligand oxygen increases the order of water molecules in the solution (e. g. Firz 1975). The entropies of ligands in water solution are given in Table 2. As Table 2 shows, the entropies of the ligands are in a negative correlation to the pKa-values of the acids. The strong adsorption of the anions of weak acids is due to the low

\begin{tabular}{|c|c|c|c|c|c|}
\hline $\mathrm{H}_{2} \mathrm{O}$ & 70 & $\begin{array}{l}\mathrm{NO}_{3}^{-} \\
\mathrm{HSO}_{4}^{-} \\
\mathrm{H}_{2} \mathrm{PO}_{4}^{-} \\
\mathrm{HSeO}_{3}^{-} \\
\mathrm{HCO}_{3}^{-} \\
\mathrm{H}_{2} \mathrm{BO}_{3}^{-} \\
\mathrm{OH}^{-}\end{array}$ & $\begin{array}{r}146 \\
127 \\
89 \\
127 \\
95 \\
31 \\
-10\end{array}$ & $\begin{array}{c}\mathrm{SO}_{4}^{\bar{z}} \\
\mathrm{HPO}_{4}^{-} \\
\mathrm{SeO}_{3}^{-} \\
\mathrm{CO}_{3}^{\overline{7}}\end{array}$ & $\begin{array}{r}17 \\
-36 \\
24 \\
-53\end{array}$ \\
\hline
\end{tabular}
entropy of these anions in the water solution.

Table 2. The entropies of ligands in water solution $\mathrm{J} / \mathrm{mol} \mathrm{K}$. The entropy of standard ion $\mathrm{H}+$ is $\mathrm{O}$ (RossinI et al. 1952). 


\section{The adsorption of anion and $\mathrm{pH}$}

Hingston et al. (1968) have stated that the adsorption of many anions to $\mathrm{Al}$ - and Fe-oxides reaches a maximum where the $\mathrm{pH}$-value is of the same order as the pKa of the corresponding acid. This result is easily explained by the theory presented above. When the $\mathrm{pH}$ of the equilibrium solution is much below the pKa-value, the concentration of the anion in solution is low, because $\mathrm{H}^{+}$competes with $\mathrm{Al}^{3+}$ and $\mathrm{Fe}^{3+}$ of oxides for anions. If the $\mathrm{pH}$ of a solution is near the $\mathrm{pKa}$, the rise in the $\mathrm{pH}$ greatly increases the degree of dissociation of the acid. When the $\mathrm{pH}$ becomes higher than the pKa-value, the degree of dissociation becomes near 1 and can change only slightly. On the other hand when the concentration of $\mathrm{OH}$-ions in a solution rises, the adsorption of $\mathrm{OH}$-groups is increased, but the adsorption of other anions is decreased.

The relationship between the $\mathrm{pH}$ and the adsorption of anions can be studied as follows:

$\mathrm{X}_{\mathrm{A}}^{\mathrm{S}}=$ the amount of adsorbed anions $\mathrm{mmol} / \mathrm{kg}$ of soil (or oxides)

$\mathrm{X}_{\mathrm{H}_{2} \mathrm{O}} \cdot \mathrm{m}=$ the amount of water adsorbed $\mathrm{mmol} / \mathrm{kg}$

$\mathrm{C}_{\mathrm{A}}=$ the concentration of anion in the solution $\mathrm{mmol} / \mathrm{l}$

$\mathrm{x}_{\mathrm{OH}}^{*}=$ the amount of adsorbed $\mathrm{OH} \mathrm{mmol} / \mathrm{kg}$

$\mathrm{C}_{\mathrm{OH}}=$ the concentration of $\mathrm{OH}$ in solution $\mathrm{mmol} / \mathrm{l}$

$\mathrm{C}_{\mathrm{H}}=$ the concentration of hydrogen ion in solution $\mathrm{mmol} / \mathrm{l}$

$\mathrm{C}_{\mathrm{HA}}=$ the concentration of acid corresponding to the ligand in solution mmol/

$\theta_{\mathrm{A}}=$ the fractional surface coverage by anion

$\mathrm{K}_{1}=\frac{\mathrm{X}_{\mathrm{A}}^{\prime}}{\mathrm{C}_{\mathrm{A}} \mathrm{x}_{\mathrm{H}_{2} \mathrm{O}}^{\prime}} ; \mathrm{x}_{\mathrm{A}}^{\prime}=\mathrm{K}_{1} \mathrm{C}_{\mathrm{A}} \mathrm{x}_{\mathrm{H}_{2} \mathrm{O}}^{\prime}$

$\mathrm{K}_{2}=\frac{\mathrm{x}_{\mathrm{OH}}^{\prime}}{\mathrm{C}_{\mathrm{OH}} \mathrm{x}_{\mathrm{H}_{2} \mathrm{O}}^{\prime}} ; \mathrm{x}_{\mathrm{OH}}^{\prime}=\mathrm{K}_{2} \mathrm{C}_{\mathrm{OH}} \mathrm{x}_{\mathrm{H}_{2} \mathrm{O}}^{\prime}$

The constants $K_{1}$ and $K_{2}$ show the equilibrium of exchange of anion and $\mathrm{OH}$ with the coordination water. Theoretically the values of $\mathrm{K}_{1}$ and $\mathrm{K}_{2}$ can be determined using the Langmuir equation.

However, it is very difficult to determine the amount of $\mathrm{H}_{2} \mathrm{O}$ and $\mathrm{OH}$ adsorbed on the surface of oxides. The strong nucleophilic character of $\mathrm{OH}$ is seen e. g. from the fact that the Al- and Fe-oxides do not adsorb sulphate, when the $\mathrm{pH}$ is above the zero point of charge (zpc), which for oxides can be about 8 (Hingston et al. 1972). An approximate idea of the value of $\mathrm{K}_{2}$ can be had by supposing that half of the adsorption sites of $\mathrm{H}_{2} \mathrm{O}$ are occupied by $\mathrm{OH}$, when the $\mathrm{pH}$ of the solution is 7 . The concentration $\mathrm{C}_{\mathrm{OH}}$ is in this case $10^{-4} \mathrm{mmol} / 1$ and $\theta_{\mathrm{OH}}$ has a value of 0.5 .

$$
\theta_{\mathrm{OH}}=\frac{\mathrm{K}_{2} \mathrm{C}_{\mathrm{OH}}}{1+\mathrm{K}_{2} \mathrm{C}_{\mathrm{OH}}} \longrightarrow \mathrm{K}_{2}=10^{4} 1 / \mathrm{mmo} 1
$$


If $\mathrm{H}_{2} \mathrm{O}, \mathrm{A}^{-}$an $\mathrm{OH}$ are the only adsorbing ligands, the number of adsorption sites in the soil (oxides) according to equations (7) and (8) can be formulated as follows:

$$
\mathrm{x}_{\mathrm{H}_{2} \mathrm{O}}^{\mathrm{v}}+\mathrm{K}_{1} \mathrm{C}_{\mathrm{A}} \mathrm{x}_{\mathrm{H}_{2} \mathrm{O}}^{\prime}+\mathrm{K}_{2} \mathrm{C}_{\mathrm{OH}} \mathrm{x}_{\mathrm{H}_{2} \mathrm{O}}^{\prime}
$$

The combining the equations (7) and (9)

$$
\theta_{\mathrm{A}}=\frac{\mathrm{K}_{1} \mathrm{C}_{\mathrm{A}}}{1+\mathrm{K}_{1} \mathrm{C}_{\mathrm{A}}+\mathrm{K}_{2} \mathrm{C}_{\mathrm{OH}}}
$$

Let $\mathrm{Ka}$ be the acid constant corresponding to the anion:

$$
\begin{aligned}
\mathrm{HA} & \longrightarrow \mathrm{H}^{+}+\mathrm{A}^{-} \\
\mathrm{Ka} & =\frac{\mathrm{C}_{\mathrm{H}} / 1000 \quad \mathrm{C}_{\mathrm{A}} / 1000}{\mathrm{C}_{\mathrm{HA}} / 1000} \\
\mathrm{C} & =\mathrm{C}_{\mathrm{HA}}+\mathrm{C}_{\mathrm{A}}^{-} \mathrm{mmol} / 1 \\
\mathrm{C}_{\mathrm{A}} & =\frac{1000 \mathrm{Ka} \mathrm{C}}{1000 \mathrm{Ka}+\mathrm{C}_{\mathrm{H}}}
\end{aligned}
$$

The last equation was combined with the equation (10) and the curves in Figure 1 were calculated using the value $10^{4}$ for the constant $\mathrm{K}_{2}$. The curves show that the maximum adsorption of the anions is near the pKa-value. The rise in the $\mathrm{pH}$ has only a negative effect on the adsorption of the anion, whose $\mathrm{pKa}$ is small. If the $\mathrm{pKa}$ is high, then adsorption below $\mathrm{pH} 7$ is weak. Silicate is an anion of this kind. The maximum degree of adsorption is near the pKavalue 9.7 (Hingston et al. 1968). If an anion is polyprotic like for example

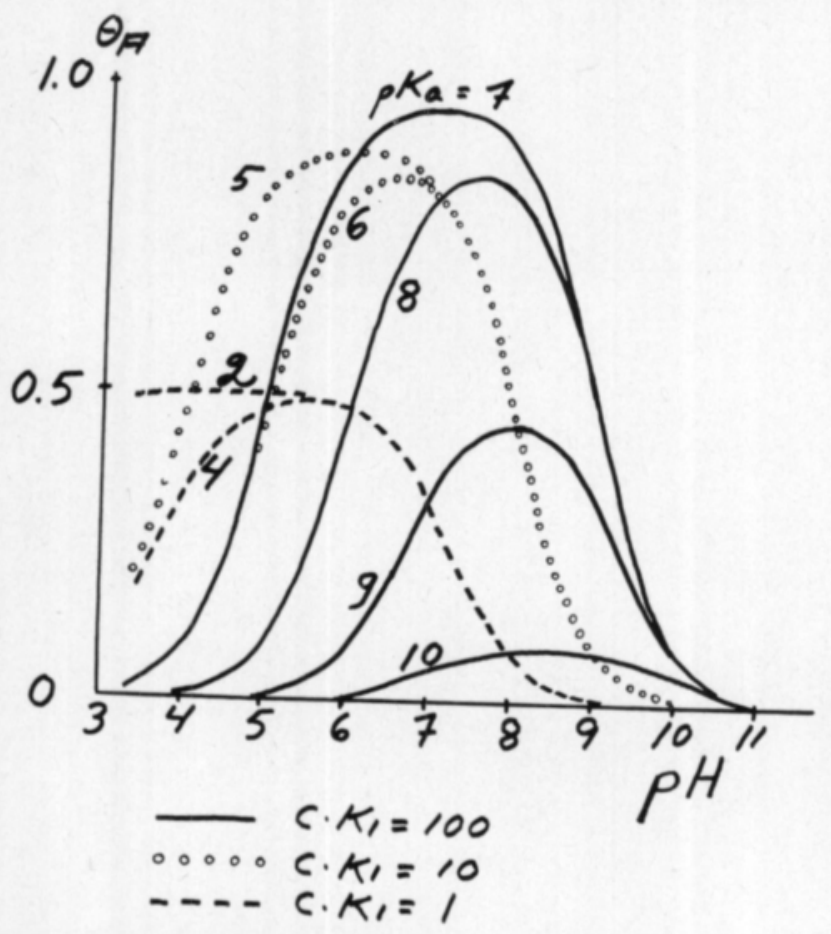

Fig. 1. Adsorption of anions onto oxides and $\mathrm{pH}$ of equilibrium solution. The curves are calculated using the equation (10). 
phosphate, the decrease of adsorption with the rise in the $\mathrm{pH}$ is less than for an anion, which dissociates with only one $\mathrm{H}^{+}$. The dissociation of more than one hydrogen ion increases the nucleophilic strength of the anion. When the $\mathrm{pH}$ rises above the last $\mathrm{pKa}$-value of the polyprotic anion, the competing effect of $\mathrm{OH}$ becomes clearer. The adsorption decreases more sharply than when the $\mathrm{pH}$ is near the other $\mathrm{pKa}$-values of the polyprotic anion as shown experimentally by Hingston et al. (1968).

\section{Kinetics of ligand exchange}

The rate of the ligand exchange also depends on the nucleophilic strength of the ligand oxygen. The rate of the exchange of ligand is especially related to the basicity of the ligand, if the central ion is a hard Lewis acid such as $\mathrm{Al}^{3+}$ or $\mathrm{Fe}^{3+}$. The high $\mathrm{pKa}$ shows a high nucleophilic reactivity of oxygen (EDwards 1956, EdWARds and PEARson 1962). Correspondingly the detachment of ligand oxygen becomes slower, when the pKa-value rises. The coordination water is not tightly bound by the central ions, and the exchange of coordinated water occurs rapidly. The first order rate constant for the removal of water molecule from the first coordination sphere of $\mathrm{Fe}^{3+}$ is about $10^{4} \mathrm{~s}^{-1}$ (Connick and STOver 1961). The difference between the rates of adsorption and desorption is distinct in the sorption of an anion, which is tightly bound by oxides. For example phosphate is rapidly bound by $\mathrm{Al}$ - or Fe-oxides, but $100 \%$ desorption is almost impossible, when ligands, which are not strongly adsorbed by oxides, are used as exchangers (Hingston et al. 1974). The micropore structure of hydrous oxides also apparently slows down the desorption of strongly bound phosphate from acid soil (AURA 1978).

The rate of the exchange of hydroxyl with water is an exception. The hydroxyl oxygen is very nucleophilic, and easily takes up a proton to form water. The hydroxyl oxygen does not need to be released from the central ion. The easily moving proton can be detached from the water in solution and associated with the OH-group on the surface of the oxides (FITZ 1975 p. 385).

\section{Discussion}

The slow desorption of phosphate from aluminium and iron oxides can be explained by the fact that phosphate can be bound to two adjacent central ions in the oxides forming a ring structure. This structure probably stabilizes the bond between phosphate and oxide, but the ring structure does not alone explain the strong adsorption of phosphate to oxides. For example sulphate forms the ring structure, when it is bound by $\mathrm{Al}$ - and Fe-oxides (PARFITT and Smart 1978, RaJan 1978), but is desorbed from oxides much more easily than phosphate. Primarily the nucleophilic strength of the ligand oxygen determines the bond between anion and $\mathrm{Al}^{3+}$ or $\mathrm{Fe}^{3+}$ of oxides.

Both carboxyl and phenolic $\mathrm{OH}$ group of soil organic matter bind $\mathrm{Al}^{3+}$ and $\mathrm{Fe}^{3+}$ (Schnitzer and SkInNer 1965). Since the pKa-value of carboxyl and phenolic $\mathrm{OH}$ groups varies greatly, there are great differences between carboxyl groups and between phenolic $\mathrm{OH}$ groups in the bonding to $\mathrm{Al}^{3+}$ or 
$\mathrm{Fe}^{3+}$. Large organic molecules are easily bound to oxides by several carboxyl and phenolic $\mathrm{OH}$ groups, which stabilize the association between organic molecules and oxides.

The ligands can be grouped as follows. The anions, which are more weakly adsorbed than water, form the first group. These anions are outside the coordination sphere of the aluminium and iron and can be bound only by oxides, if the surface of oxides is positively charged. Nitrate belongs to this group (SERnA et al. 1977). The second group are anions, which are more strongly bound than water to the oxides, but cannot change the structure of oxides. Sulphate belongs to this group (Hingston et al. 1972, RAJAN 1979). In the third group are the anions, which are firmly bound by oxides above zpc making the surface of oxide more negative. Anions of this type can radically change the structure of oxides, if the anion concentration in equilibrium solution is high enough. Phosphate (RAJAN et al. 1974) and hydroxyl are in this group. Humus molecules belong to the third group (SchNitzer and SKINNER 1963) as does silicate when the $\mathrm{pH}$ is above 7 (Hingston and RAUPACH 1967). Molybdate and selenite are apparently in the second group.

If an anion is not able to exchange the coordination water from the surface of oxides, the diffusion of the anion in soil is rapid. The anion is easily carried in soil by mass flow. The activation energy of diffusion in soil is about the same as in water solution or about $20 \mathrm{~kJ} / \mathrm{mol}$ (GLASTONE et al. 1941, p. 401). When an anion coordinates with the central ions of oxides, the diffusing anion is repeteadly bound by the oxides. The high nucleophilic strength of the anion slows down its detachment from the central ions of oxide and decreases the diffusion coefficient of the anion in soil. For example the diffusion coefficient of nitrate in soil is about $10^{-5} \mathrm{~cm}^{2} / \mathrm{s}$ and that of phosphate $10^{-9} \mathrm{~cm}^{2} / \mathrm{s}$ (NYE and TINKER 1977 p. 82). The dependence of the diffusion coefficient on the temperature is higher for those anions that coordinate with the central ions of oxides than for those anions that are outside the coordination sphere (see AURA 1978).

Since the bond between phosphate and $\mathrm{Al}^{3+}$ or $\mathrm{Fe}^{3+}$ is strong, the movement of phosphate in soil by mass flow is slight. The strong adsorption of anions to oxides reduces the leaching from the cultivated layer. When a plant takes phosphorus from the soil, a determining factor in the process is the slow diffusion of phosphate in the soil surrounding the root surface and root hairs (NyE and TINKER 1977). The uptake of phosphate by mass flow is slight. Since the diffusion coefficient of phosphate depends strongly on the temperature, the rise of soil temperature has a considerable positive effect on the uptake of phosphate from soil. 


\section{REFERENCES}

AURA, E. 1978. Phosphate desorption from soil in anion-exchange resin extraction. J. Scient. Agric. Soc. Finl. 50: 335-345.

Baran, V. 1971. Hydroxyl ion as a ligand. Coord. Chem. Rev. 6: 65-93.

Basolo, F. \& Pearson, R. G. 1967. Mechanisms of inorganic reactions. 670 p. New York.

Biggar, J. W. \& Fireman, M. 1960. Boron adsorption and release by soils. Soil Sci. Soc. Amer. Proc. 24: 115-120.

Bingham, F. T., Page, A. L., Coleman, N. T. \& Flach, K. 1971. Boron adsorption characteristics of selected amorphous soils from Mexico and Hawaii. Soil Sci. Soc. Amer. Proc. 35: 546-550.

Clark, J. S. 1964. Aluminium and iron fixation in relation to exchangeable hydrogen in soils. Soil Sci. 98: 302-306.

Connick, R. E. \& STover, E. D. 1961. Rate of elimination of water molecules from the first coordination sphere of paramagnetic cations as detected by nuclear magnetic resonance measurements of $\mathrm{O}^{17}$. J. Phys. Chem. 65: 2075-2077.

Edwards, J. O. 1956. Polarizability, basicity and nucleophilic character. J. Amer. Chem. Soc. 76: 1819-1820.

- \& Pearson, R. G. 1962. The factors determining nucleophilic reactivities. J. Amer.

Chem. Soc. $84: 16-24$.

Frrz, I. 1975. Reaktionstypen in der anorganischen Chemie. 465 p. Berlin.

Glastone, S., Laidler, K. J. \& Eyring, H. 1941. The theory of rate processes. 611 p. New York.

Hartikainen, H. 1979. Phosphorus and its reactions in terrestrial soils and lake sediments. J. Scient. Agric. Soc. Finl. 51: 537-624.

Hingston, F. J., Atrinson, R. J., Posner, A. M. \& Quirk, J. P. 1968. Specific adsorption of anions on goethite. Trans. 9th Intern. Gongr. Soil Sci. I: 669-678.

- , Posner, A. M. \& QUIRK, J. P. 1972. Anion adsorption by goethite and gibbsite. I. The role of the proton in determining adsorption envelopes. J. Soil Sci. 23: 177-192.

- , Posner, A. M. \& Quirk, J. P. 1974. Anion adsorption by goethite and gibbsite. II. Desorption of anions from hydrous oxide surfaces. J. Soil Sci. 25: 16-26.

- \& Raupach, F. J. 1967. The reaction between monosilicic acid and aluminium hydroxide. 1. Kinetics of adsorption of silicic acid by aluminium hydroxide. Aust. J. Soil Res. 5: 295-309.

Hunt, J. P. 1963. Metal ions in aqueous solution. 121 p. New York.

JACKson, M. L. 1960. Structural role of hydronium in layer silicates during soil genesis. Trans. 7th Intern. Congr. Soil Sci. II: $445-455$.

Murphy, P. J., Posner, A. M. \& Quirk, J. P. 1975. Chemistry of iron in soils. Ferric hydrolysis products. Aust. J. Soil Res. 13: 189-201.

Nye, P. H. \& TINker, P. B. 1977. Solute movement in the soil root system. 342 p. Oxford.

PARfitT, G. D. 1971. Introductory lecture. Discussions of Faraday Soc. 52: 9-13.

Parfitt, R. L., Atkinson, R. J. \& Smart, R. C. 1975. The mechanisms of phosphate fixation by iron oxides. Soil Sci. Soc. Amer. Proc. 39: 837-841.

- \& Smart, R. C. 1978. The mechanism of sulfate adsorption on iron oxides. Soil Sci. Soc. Amer. J. 42: 48-50.

Pearson, R. G. 1966. Acids and bases. Science 151: 172-177.

RAJAN, S. S. S. 1978. Sulfate adsorbed on hydrous alumina, ligands displaced, and changes in surface charge. Soil Sci. Soc. Amer. J. 42: 39-44.

- 1979. Adsorption and desorption of sulfate and charge relationships in allophanic clays. Soil Sci. Soc. Amer. J. 43: 65-69.

- , Perrot, K. W. \& Saunders, W. M. H. 1974. Identification of phosphate-reactive sites of hydrous alumina from proton consumption during phosphate adsorption at constant $\mathrm{pH}$ values. J. Soil Sci. 25: 438-447.

ReYes, E. D. \& JuRINAK, J. J. 1967. A mechanism of molybdate adsorption on $\boldsymbol{\alpha}-\mathrm{Fe}_{2} \mathrm{O}_{3}$. Soil Sci. Soc. Amer. Proc. 31: 637-640.

Rossini, F. R., Wagman, D. D., Evans, W. H., Levine, S. \& Jaffe, I. 1952. Selected values of chemical thermodynamic properties. 1267 p. Washington. 
SAsAKI, Y., Lindovist, I. \& Sillen, L. G. 1959. On the first equilibrium steps in the acidification of the molybdate ion. J. Inorg. Nuc. Chem. 9: 93-94.

Schnitzer, M. 1978. Humic substances: Chemistry and reactions. In Schenitzer, M. \& Kнan, S. U. (ed.) Soil organic matter. Development in soil science 8:1-58. 319 p. Oxford.

- \& SKINNER, S. I. M. 1963. Organo-metallic interactions in soils: 2. Reactions between different forms of iron and aluminium and the organic matter of a podzol $\mathrm{B}_{\mathrm{H}}$ horizon. Soil Sci. 96: 181-186.

- \& SKInNeR, S. I. M. 1965. Organo-metallic interactions in soils: 4. Carboxyl and hydroxyl groups in organic matter and metal retention. Soil Sci. 99: 278-284.

Serna, C. J., White, J. L. \& Hem, S. L. 1977. Anion-aluminium hydroxide gel interactions. Soil Sci. Soc. Amer. J. 41: 1009-1013.

Syers, J. K., Browman, M. G., Smillie, G. W. \& Corey, R. B. 1973. Phosphate sorption by soils evaluated by the Langmuir adsorption equation. Soil Sci. Soc. Amer. Proc. 37: $358-363$.

WeAst, R. C. 1969. Handbook of chemistry and physics. 2356 p. Cleveland.

Ms received September 24, 1979.

\title{
SELOSTUS
}

\section{Happi vaihtuvana ligandina maassa}

\author{
ERKKI AURA ${ }^{1}$ ) \\ Helsingin yliopiston maanviljelyskemian laitos, 00710 Helsinki 71
}

Anioninvaihto kuuluu kuten kationinvaihtokin maaperäkemian keskeisimpiin ilmiöihin. Teoreettisen tarkastelun avulla pyrittiin selvittämään eri happiligandien pidättymistä polymeeristen alumiini- ja rautaoksidien pinnoille. Anionin sitoutuminen oksidien $\mathrm{Al}^{3}+$ tai $\mathrm{Fe}^{3+-}$ ioneihin riippuu erityisesti ligandihapen kyvystä luovuttaa elektroneja ligandin ja keskusionin väliseen sidokseen. Koska protoni on kuten $\mathrm{Al}^{3}+$ tai $\mathrm{Fe}^{3}+$ tyypillinen elektronien vastaanottaja eli Lewisin happo, anionia vastaava happovakio pKa ilmaisee anionin taipumusta sitoutua oksideihin. Mitä helpommin ligandihappi luovuttaa elektroneja keskusionille, sitä vahvempi sidos muodostuu hapen ja keskusionin välille. Vahva kovalenttinen sidos ei kuitenkaan merkitse, että anionin adsorptio oksidien pinnoille olisi aina eksoterminen reaktio. Lähinnä entropiasuhteet määrääät vaihdon tasapainon.

Esitetty teoria selittää anionien pidättymisen ja $\mathrm{pH}: \mathrm{n}$ välisen yhteyden. Pidättyminen oksideihin on voimakkainta, kun $\mathrm{pH}$ on suunnilleen sama kuin anionia vastaavan hapon pKaarvo. Kun maan kanssa tasapainossa olevan liuoksen $\mathrm{pH}$ on paljon alle pKa-arvon, anionin konsentraatio liuoksessa on hyvin pieni, koska $\mathrm{H}+$ - ioni kilpailee oksidien $\mathrm{Al}^{3+}: \mathrm{n}$ ja $\mathrm{Fe}^{3+}: \mathrm{n}$ kanssa sitoutumisesta anioniin. Kun liuoksen $\mathrm{pH}$ on suunnilleen $\mathrm{pKa}$, happamuuden väheneminen lisää nopeasti anionia vastaavan hapon dissosioitumisastetta. Kun pH on paljon yli pKaarvon, anionia vastaava happo on lähes täysin dissoisoitunut. Kuitenkin liuoksen OH-konsentraatio kasvaa edelleen $\mathrm{pH}: n$ suuretessa, mikä lisää $\mathrm{OH}: n$ pidättymistä oksidien pinnalle, mutta vähentää muiden anionien adsorptiota.

Ligandihapen taipumus luovuttaa elektroneja keskusionille vaikuttaa myös vaihdon kinetiikkaan. Voimakkaasti sitoutuva anioni reagoi nopeasti oksidien pinnan $\mathrm{Al}^{3+}: \mathrm{n}$ ja $\mathrm{Fe}^{3+}: \mathrm{n}$ kanssa, mutta tällaisten anionien irroittaminen oksideista käyttäen heikosti sitoutuvia ligandeja on vaikeaa. Esitetyn teorian avulla voidaan selittää useita anionien huuhtoutumiseen tai kasvin ravinteiden saantiin vaikuttavia tekijöitä.

1) Nykyinen osoite: Maatalouden tutkimuskeskus, maanviljelyskemian ja -fysiikan laitos 31600 Jokioinen. 